URL https://zakon.rada.gov.ua/rada/show/v0417282-11\#Text (дата звернення 28.03.2021).

9. Про удосконалення медичного обслуговування учнів загальноосвітніх навчальних закладів: Наказ МО3 України від 16.08.2010 № 682 / MO3 України. URL https://zakon.rada.gov.ua/laws/show/z079410\#Text (дата звернення 28.03.2021).

DOI https://doi.org/10.30525/978-9934-26-075-9-24

\title{
ЗНАЧЕННЯ КОМПЛЕКСНОГО НЕЙРОВІЗУАЛЬНОГО ОБСТЕЖЕННЯ ХВОРИХ НА ЦЕРЕБРОВАСКУЛЯРНІ ЗАХВОРЮВАННЯ
}

\section{Степаненко I. B.}

доктор медичних наук, старший науковий співробітник, завідувачка відділення нейрореабілітації ДУ «Інститут нейрохірургї імені академіка А. П. Ромоданова Національної академії медичних наук України»

Попова І. Ю.

кандидат медичних наук, лікар відділення нейрореабілітаиіі

ДУ «Інститут нейрохірургії імені академіка А. П. Ромоданова Начіональної академії медичних наук Украӥни»

Лукашевич П. В.

кандидат медичних наук, лікар відділення нейрореабілітації

ДУ «Інститут нейрохірурсї імені академіка А. П. Ромоданова Національної академії медичних наук України»

\section{Лихачова Т. А.}

лікар відділення нейрореабілітаиії

ДУ «Інститут нейрохірургї імені академіка А. П. Ромоданова Національної академії медичних наук Украӥни» м. Київ, Україна

Уточнення характеру змін головного мозку при цереброваскулярних захворюваннях різної тяжкості має велике значення для об'єктивної 
оцінки стану пацієнта та встановлення груп підвищеного ризику розвитку тяжких форм захворювання. В зв'язку з цим було вивчено інформативність комплексного обстеження хворих 3 використанням різних нейровізуалізуальних методів.

Було обстежено 70 хворих на хронічну ішемію мозку (XIM) у віці 40-67 років, чоловіків - 36, жінок - 34 осіб. 3 ХІМ І ст. - 14, II ст. - 36, III ст. - 20 хворих. Клінічний стан пацієнтів оцінювався за глибиною неврологічних порушень за 5-бальною шкалою та за індексом активності - Activity Index (AI) [1].

3 метою більш детальної оцінки характеру змін головного мозку, встановлення значення стану церебральної гемодинаміки і мозкової перфузії в розвитку цих змін було проведене комплексне обстеження нейровізуальними методами, які включали: ультразвукову допплерографію судин головного мозку (УЗДГ) [2]; магнітно-резонансну томографію (МРТ) і однофотонну емісійну комп'ютерну томографію (ОФЕКТ) $[3,4]$. Проведення таких досліджень обумовлювалось тим, що уточнення уявлень про патофізіологічну сутність і механізми розвитку уражень головного мозку поряд 3 визначенням функціонального перфузійного резерву цереброваскулярного русла має велике значення не тільки в прогнозуванні перебігу захворювання, але і в виборі адекватних методів лікування і профілактики розвитку тяжких форм захворювання.

Обстеження методом УЗДГ дозволяє вивчити транспортну фазу кровопостачання мозку, оцінити стан церебральної гемодинаміки в кожному басейні, виявити морфологічні зміни екстра- та інтракраніальних артерій, еластико-тонічні властивості судинної стінки i зниження механізмів ауторегуляції судин [2].

Метою дослідження на МРТ було виявлення структурних змін головного мозку з урахуванням тяжкості ХIM. Оцінювалась наявність атрофічного процесу і вогнищевих змін головного мозку. Окремо враховувалась вираженість атрофічного процесу у вигляді розширення шлуночкової системи (внутрішньої гідроцефалії), а також вогнищеві зміни - дрібновогнищеві (діаметром до 0,1-0,3 см) і більш виражені, 3 діаметром більше $0,4-0,5 \mathrm{~cm}$.

Використання для діагностики характеру і ступеню ураження головного мозку ОФЕКТ дозволяє оцінити ступінь зниження функціональної активності мозку при дисциркуляторних порушеннях, а також розраховувати об'єм ураженої тканини головного мозку [3].

Встановлено, що практично у всіх хворих виявлялись достовірні, порівняно 3 контрольною групою, зміни показників УЗДГ: фізіологічна допплерограма (ДГ) реєструвалась лише у 5,3\% хворих, зміни 
гіпертонічного типу - у 86,8\%, атеросклеротичного - у 50\%, зниження PI в вертебро-базилярному басейні (ВББ) - у 47,4\%, а в обох басейнах - у 87\%. Зниження лінійної швидкості кровотоку (ЛШК) в ВББ встановлено у 47,4\%, тоді як в каротидному басейні (КБ) лише у 18,4\%. Поряд 3 цим, у $42,1 \%$ в ВББ і у 5,3\% хворих в КБ виявлялась асиметрія ЛШК, що свідчило про наявність в них ознак спазму або стенозу однієї з артерій. Коефіцієнт асиметрії відповідав 12-50\% 3 переважанням змін зліва, де зниження ЛШК виявлялось в 3 рази частіше, ніж справа. Крім того, виявлялись ознаки ангіоспазму судин КБ. Венозна дисциркуляція встановлена у 89,5\%. При цьому і периферичний судинний опір (ПСО) був суттєво підвищений у 63,2\% хворих, наявність якого свідчить про порушення еластико-тонічних властивостей судинної стінки і сприяє підтримці венозної дисциркуляції. Виявлені порушення відповідали тяжкості XIM, однак у частини хворих простежувалась відносна незалежність вираженості неврологічної симптоматики від ступеню органічних змін судин головного мозку, особливо в ВББ. У інших хворих навпаки, виражені зміни виявлялись при відносно задовільній клінічній симптоматиці.

При МРТ-дослідженні встановлено зміни у 85\% хворих. Ці порушення можна поділити слідуючим чином: 1. ознаки атрофічного процесу у вигляді розширення субарахноідальних просторів, у деяких хворих - i шлуночкової системи; 2. різного розміру множинні розсіяні гіперінтенсивні вогнища на Т2-зважених зображеннях в межах білої речовини в перивентрикулярних ділянках супратенторіальних відділів головного мозку без ознак мас-ефекту; 3. вогнищеві ураження головного мозку ішемічного характеру. 3 тяжкістю XIM корелювали фактично всі виявлені порушення, але особливо - вираженість атрофічного процесу, зокрема гідроцефальні зміни, величина і частота вогнищевих порушень. Проте у частини хворих $(28,6 \%)$ 3 I і II ст. ХIM виражені зміни на МРТ не корелювали 3 клінічним станом і не співпадали 3 перенесеним в анамнезі гострим або минучим порушенням мозкового кровообігу, у інших (17\%) - виражена неврологічна сиптоматика не супроводжувалась відповідними змінами на МРТ. Гіперінтенсивні дрібновогнищеві зміни (в режимі Т2 WI), як правило були множинні (лише у окремих хворих одиничні), локалізувались супратенторіально, в перивентрикулярних ділянках, в межах білої речовини (лейкоареоз) і підкіркової зони і не викликали мас-ефекту. Походження i локалізацію таких дрібновогнищевих змін при ХІМ пояснюють тим, що перивентрикулярна біла речовина представляє собою територію, де піальні артерії кори півкуль стикуються 3 пенетруючими гілками великих мозкових судин, що 
зумовлює велику чутливість перивентрикулярної білої речовини до ішемії [5]. У двох хворих більш виражені вогнищеві зміни були оцінені як ішемічні, тобто свідчили про перенесене гостре порушення мозкового кровообігу (ГПМК). Однак анамнестично ці хворі перенесення ГПМК не підтвердили.

При ОФЕКТ-дослідженні порушення мозкової перфузії виявлено у 88,6\% пацієнтів, які можна оцінити, як: 1. дифузні (26\% хворих) і 2. вогнищеві (74\%). Серед вогнищевих порушень були виділені дифузновогнищеві, багатовогнищеві (двобічні) та одиничні вогнищеві зниження перфузії. Найчастіше гіпоперфузія спостерігалась в проекції білої речовини i, переважно, зліва, що збігалось з результатами УЗДГ- і МРТдосліджень [6]. У 5 хворих виявлявся крос - церебелярний діашиз (КЦД) або перехресний мозочковий діашиз, тобто зниження мозкової перфузії в протилежній півкулі мозочка 3 одночасним виявленням вогнищ зниження перфузії в півкулях мозку [4, 7]. Виявлення КЦД, або вогнища «на віддаленні», являється важливою ознакою наявності ГПМК, а причиною цього явища вважають пригнічення інтегральної синаптичної активності [5]. Воно являється свідченням наявності як оборотного зниження функціональної активності, так і дегенеративних процесів, але завжди є серйозною ознакою дефектності кровопостачання мозку. При зростанні тяжкості ХІМ суттєво зростала вираженість дифузних, а також частота і вираженість багатовогнищевих порушень (55\%). Однобічні вогнищеві порушення зустрічались переважно при II ст. XIM. У частини хворих з I і II ст. XIM (32\%) зміни мозкової перфузії не відповідали вираженості клінічної симптоматики. Дифузні i дифузно-вогнищеві порушення пефузії в більшості випадків співпадали 3 атрофічними i дрібновогнищевими змінами на МРТ, проте частота i вираженість вогнищевих порушень на ОФЕКТ була більшою, ніж при дослідженні методом МРТ [8].

Висновки. Таким чином, отримані дані свідчать про високу інформативність застосованих методів дослідження, серед яких особливе значення має ОФЕКТ. Кожен з цих методів дозволяє виявити окремі ланки, що складають патофізіологічну основу ХІМ - транспортну фазу кровообігу, структурно-анатомічні зміни мозкової тканини, стан тканинного кровотоку (перфузіі). Це підвищує діагностичну інформативність комплексного обстеження в оцінці характеру змін головного мозку і дозволяє виявити групи ризику в розвитку тяжких форм захворювання. До таких груп можна віднести хворих з задовільним неврологічним станом, але 3 вираженими змінами, виявленими нейровізуальними методами. Такі хворі потребують ретельного спостереження і постійного 
диспансерного нагляду. Інша група хворих, 3 вираженою клінічною симптоматикою, але без суттєвих змін при нейровізуальному дослідженні, також потребують диспансерного нагляду і лікування 3 метою запобігання прогресування захворювання і профілактики розвитку тяжких форм XIM.

\section{Література:}

1. Hamrin E., Wohlin A. Evaluation of the functional capacity of stroke patients through an Activity Index. Scand. J. Rehab. Med. 1982. Vol. 14, № 3. Р. 93-100.

2. Калашников В.И. Допплерографическая диагностика состояния цереброваскулярной реактивности у больных с хроническими ишемическими нарушениями мозгового кровообращения различной стадии. Укр. мед. часопис. 2000. № 6(20). С. 98-102.

3. Лишманов Ю.Б. Радионуклидная диагностика для практических врачей: монографія / за ред. В.И.Чернова. Томск. 2004. 394 с.

4. Sugawara Y. SPECT evaluation of cerebral perfusion reserve in patients with occlusive cerebrovascular disease. Evaluation with acetazolamide test and crossed cerebellar diashisis. Kaku-Igaku. 1995. Vol. 32, № 3. P. 287-299.

5. Baron J.C. Testing cerebral function: will it help the understanding of diagnosis of CNS disease? CIBA Foundation Symposium. London. 1991. № 163. P. 250-264.

6. Kireşi D., Taştekin G., Cengiz S.L., Ustün M.E., Yürüten B. Correlation of magnetic resonance imaging findings with hexamethylpropyleneamine oxime brain single photon emission computed tomography in ischemic stroke patients in the subacute stage. Acta Radiol. 2006. Vol. 47, № 4. P. 401-407.

7. Marco Iacoboni, Jean-Claude Baron, Richard S.J. Frackowiak, John C. Mazziotta, Gian Luigi Lenzi. Emission tomography contribution to clinical neurology. Clin. Neurophysiology. 1999. № 110. Р. 2-23.

8. Ефимова Н.Ю, Чернов В. И., Ефимова И. Ю., Трисс С. В., Лукьяненок П.И., Лишманов Ю.Б. Однофотонная эмиссионная компьютерная томография С99mТc-ГМПАО в оценке церебральных нарушений у больных эссенциальной гипертонией: взаимосвязь с когнитивной функцией и структурными изменениями головного мозга. Медищинская радиология и радиационная безопасность. 2007. Том 52, N 6. С. 35-41. 